\title{
PERGOLAKAN ANTARA KEPENTINGAN DAKWAH DENGAN KEPENTINGAN POLITIK DALAM PERJUANGAN PARTAI KEADILAN SEJAHTERA (PKS) DI SULAWESI TENGGARA
}

\author{
Iyatna Supriatna \\ Muliaty Amin \\ Usman Jasad
}

\begin{abstract}
Abstrak: Tulisan ini akan mengurai tentang pergolakan antara kepentingan dakwah dengan kepentingan politik dalam perjuangan Partai Keadilan Sejahtera (PKS) di Sulawesi Tenggara.

Penelitian ini adalah penelitian lapangan (field research) yang bersifat deskriptif kualitatif. Lokasi penelitian bertempat di Kota Kendari Sulawesi Tenggara yaitu strategi dakwah PKS di kota Kendari, Kab.Muna dan Anggota legislatif. Pendekatan yang digunakan dalam penelitian ini adalah pendekatan normatif, dakwah, komunikasi dan pendekatan sosiologis. Sumber data primer berasal dari hasil wawancara peneliti dengan pengurus inti Partai Keadilan Sejahtera di Kota Kendari yakni ketua umum dan sekretaris umum, dan ketua bidang dakwah DPW Sulawesi Tenggara, sekretaris DPD PKS Kab.Muna dan anggota legislatif, tokoh masyarakat, tokoh pemuda serta dokumentasi mengenai pelatihan yang pernah diikuti oleh para kader. Data dikumpulkan melalui observasi, wawancara dan dokumentasi dengan instrumen masingmasing sesuai metodenya. Analisis data dilakukan melalui reduksi data, penyajian data, dan penarikan kesimpulan. Data diuji keabsahannya dengan triangulasi sumber dan triangulasi teknik.

Hasil penelitian menunjukkan Kepentingan dakwah dan politik dalam perjuangan PKS di Sulawesi Tenggara bukanlah menjadi persoalan yang berarti karena para kader terutama yang menjadi anggota legislatif ditingkat provinsi dan kota/kabupaten cukup dinamis dalam memerankannya. Terutama bagi mereka yang terlibat langsung dalam politik praktis, yakni mereka yang sudah teruji komitmen dan loyalitasnya terhadapa ajaran Islam. Dan tentu saja telah memiliki kredibitas yang tinggi bukan saja dalam pandangan internal partai akan tetapi dalam kehidupan masyarakat juga. Sebagaimana dalam konsep teori citra dai bahwa semakin tinggi kredibilitas seseorang maka semakin tinggi tingkat pemerimaan orang lain terhadapnya.
\end{abstract}

\section{PENDAHULUAN}

Strategi dakwah adalah upaya-upaya (cara) untuk mencapai goal atau apa yang menjadi tujuan dakwah itu sendiri. Cara yang dimaksud secara sistematik dimulai dari fact finding (mendapatkan fakta yang sesungguhnya terjadi pada masyarakat sebagai objek dakwah). Planning (perencanaan). Actuating, yaitu melaksanakan kegiatan dakwah (bi al-lisan, bi al-kitabah, bi al-hal), evaluating (mengevaluasi atau mengukur 
sejauh mana keberhasilan dakwah untuk kemudian diadakan perbaikan dan pengembangan). ${ }^{1}$

Dalam konteks keindonesiaan jalur politik memberikan ruang untuk menerapkan dakwah siyasah ini. Melalui ukuran-ukuran demokrasi dalam sistem politik negara kita, eksistensi politik dapat diwujudkan.

Pada term politik seperti sekarang wajib bagi umat Islam untuk berpolitik sebagai sarana dakwah Islam. Sebagai seorang muslim, kita tidak dapat melepaskan diri dari politik. Sebagai seorang politik kita tidak dapat melepaskan diri dari ideologi kita, yakni ideologi Islam. Bagi kita, menegakkan Islam itu tidak dapat dilepaskan dari menegakkan masyarakat, menegakkan negara, dan menegakkan kemerdekaan. ${ }^{2}$

Menurut Harun Nasution, hubungan kekuasaan dan dakwah cukup jelas. Pada periode Mekkah, Muhammad SAW sulit mengembangkan dakwah karena di Mekkah terdapat kekuasaan Qurays yang kuat menentangnya. Di Madinah, kekuasaan seperti ini tidak ada, bahkan kemudian tampak kekuasaan di Madinah dipegang oleh Muhammad SAW. Dengan kekuasaan yang ada ditangannya, ia lebih mudah menyebarluaskan ajaran Islam. ${ }^{3}$ Yang mana dikenal alat pemersatu yakni Piagam Madinah.

Pilar utama dalam sistem demokrasi yakni partai politik, dalam hal ini hampir seluruh otoritas dalam negara melalui jalur politik. Salah satu kekuatan sosial politik di Indonesia yaitu Partai Keadilan Sejahtera (PKS). PKS berdiri sejak tahun 1999 yang mulai memunculkan eksistensinya sebagai kekuatan politik baru dengan nama Partai Keadilan, kemudian Partai Keadilan Sejahtera, dimana sebelumnya dikenal oleh masyarakat sebagai organisasi tanpa bentuk. Tidak lama setelah rezim orde baru tumbang. Sepanjang perkembangan Partai Keadilan (PK) dan PKS, kader-kader partai berusaha menempatkan dakwah dan politik sebagai elemen yang tidak terpisahkan. ${ }^{4}$

PKS lahir melalui gerakan sosial bernama Tarbiyah yang kemudian bermutasi menjadi partai politik. Basis sosial partai tersebut ialah kelompok muslim terdidik, muda dan kelas menengah kota. Tidak seperti partai politik lain, PKS selalu mampu mendulang simpati publik dengan memobilisasi kader dan simpatisannya untuk melakukan kegiatan bakti sosial secara terus-menerus dan tidak hanya menjelang pemilu. PKS tampil berbeda melalui sistem kaderisasi yang terorganisir dan sistematis serta meniscayakan komitmen dan keterlibatan aktif para kadernya. Kegiatan-kegiatan keagamaan yang rutin diselenggarakan seperti halaqah dan liqo tetap menjadi aspekaspek penting dalam kehidupan partai dan anggota-anggotanya. ${ }^{5}$ Halaqah secara sederhana dalam istilah kader-kader PKS yaitu kelompok pengajian kaderisasi untuk para kader maupun pendukung yang biasanya beranggotakan 8-12 orang yang dikelola oleh seorang murabbi (guru) dan anggota pengajian dikenal dengan istilah mutarabbi. Sedangkan liqo dalam bahasa arab artinya pertemuan, yang esensinya sama dengan halaqah yakni istilah yang digunakan untuk menyebut secara umum pertemuan kelompok pengajian kaderisasi PKS. Kader yang mengabaikan loyalitas dan komitmen total terhadap nilai-nilai dakwah akan sulit berkembang di dalam partai. Kehidupan di

\footnotetext{
${ }^{1}$ Malik Idris, Strategi Dakwah Kontemporer, (Cet.I; Makassar: Sarwah Press, 2007), h. 7.

${ }^{2}$ Thohir Luth, M. Natsir: dakwah dan Pemikirannya, (Cet.I; Jakarta: Gema Insani Press, 1999), h. 85 .

${ }^{3}$ Harun Nasution, Islam Ditinjau dari Berbagai Aspeknya, (Cet. V; Jakarta: UI Press, 1985), h. 56.

${ }^{4}$ La Ode Muh. Dasnah (42 tahun), Ketua Bidang Dakwah dan Staf Ahli DPRD Provinsi Sulawesi Tenggara, Observasi dan Wawancara, 25 Juni 2015.

${ }^{5}$ La Ode Muh. Dasnah (42 tahun), Ketua Bidang Dakwah dan Staf Ahli DPRD Provinsi Sulawesi Tenggara, Observasi dan Wawancara, 25 Juni 2015.
} 
internal PKS amat kaya dan intensif. Seluruh aspek-aspek internal ini adalah manifestasi dari sebuah partai yang juga memerankan diri sebagai gerakan sosial-keagamaan.

Sebagaimana gerakan-garakan Islamis lainnya, PKS lahir dari diskusi-diskusi kecil dikalangan mahasiswa beberapa universitas yang kemudian bertransformasi menjadi gerakan politik. PKS muncul sebagai gerakan sosial Islam yang masih tetap mempertahankan karakter dasarnya dengan menambah kapasitas organisasi dan sumber dayanya. Yang mana dimulai dengan fase dakwah kampus, pembentukan gerakan mahasiswa dan gerakan politik. ${ }^{6}$

Partai Keadilan Sejahtera merupakan salah satu partai yang menjadikan politik sebagai sarana (washilah) dalam menegakkan amar ma'ruf nahy munkar. Partai politik yang PKS gunakan tersebut sebagai strategi agar tetap dapat menjalankan misinya dalam sistem demokrasi di Indonesia seperti saat ini. Sebagaimana hal tersebut dijabarkan dalam visi dan misi yang telah diusung oleh PKS.

Visi PKS adalah terwujudnya masyarakat madani yang adil, sejahtera dan bermartabat. Masyarakat madani adalah masyarakat berperadaban tinggi dan maju yang berbasiskan pada nilai-nilai, norma, hukum, moral yang ditopang oleh keimanan; menghormati pluralitas, bersikap terbuka dan demokratis; dan bergotong royong menjaga kedaulatan Negara. Pengertian genuine dari masyarakat madani itu perlu dipadukan dengan konteks masyarakat Indonesia di masa kini yang merealisasikan Ukhuwah Islamiyyah (ikatan keislaman), Ukhuwah Wathaniyyah (ikatan kebangsaan) dan Ukhuwah Basyariyyah (ikatan kemanusiaan) dalam bingkai NKRI. ${ }^{7}$

Tulisan ini akan mengurai tentang pergolakan antara kepentingan dakwah dengan kepentingan politik dalam perjuangan Partai Keadilan Sejahtera (PKS) di Sulawesi Tenggara.

\section{TEORI CITRA DAI DAN TEORI MEDAN DAKWAH}

Teori yaitu proposisi-proposisi ilmiah yang mengikat keterkaitan antara satu kaidah dengan kaidah yang lainnya dan menyatukannya pada kesatuan prinsip yang dari padanya memungkinkan diambil kepastian ketentuan dan kaidah ilmiah. ${ }^{8}$

Berdasarkan uraian di atas dapat disimpulkan bahwa teori dakwah yaitu serangkaian variabel yang sistematis dan saling berhubungan yang didalamnya menjelaskan suatu usaha baik perkataan maupun perbuatan yang mengajak manusia untuk menerima islam, mengamalkan dan berpegang teguh terhadap prinsip-prinsipnya, meyakini aqidah serta berhukum dengan syari'at-Nya.

Terdapat dua teori dakwah yang akan penulis paparkan, dimana diidentifikasi erat kaitannya dengan dakwah siyasah sebagai strategi dakwah yaitu:

a. Teori citra dai

Makna dakwah tidak hanya sekedar menyeru atau mengajak manusia, tetapi juga mengubah manusia sebagai pribadi maupun kelompok agar dapat tumbuh dan berkembang sesuai dengan fitrahnya. Dalam rangka menegakkan dakwah sehingga ajaran Islam diketahui, dipahami, dihayati dan dilaksanakan oleh umat diperlukan juru dakwah yang berkualitas. Juru dakwah tersebut adalah orang yang mengerti hakikat

${ }^{6}$ La Ode Muh. Dasnah (42 tahun), Ketua Bidang Dakwah dan Staf Ahli DPRD Provinsi Sulawesi Tenggara, Wawancara, 25 Juni 2015.

7"PKS Visi dan Misi", Situs Resmi Dewan Pengurus Pusat Partai Keadilan Sejahtera. www. Pks.or.id/mobile/content.html? (19 Mei 2015).

${ }^{8}$ Aep Kusnawan, Ilmu Dakwah (Kajian Berbagai Aspek), (Bandung: Pustaka Bani Quraisy, 2004), h. 132. 
Islam dan mengetahui apa yang sedang berkembang dalam kehidupan masyarakat. Keberhasilan kegiatan dakwah sangat ditentukan oleh kualitas dan kepribadian seorang dai. Dengan kualitas dan kepribadian tersebut seorang dai akan mendapatkan kepercayaan dan citra yang positif di mata mad'u baik individu atau masyarakat.

Kata citra pada pemahaman mayoritas seseorang adalah suatu kesan dan penilaian terhadap seseorang, kelompok, lembaga dan lain-lain. Citra yang berhubungan dengan seorang dai dalam perspektif komunikasi sangat erat kaitanya dengan kredibilitas yang dimilikinya. Kredibilitas sangat menentukan citra seseorang. Teori citra dai menjelaskan penilaian mad'u terhadap kredibilitas dai apakah dai mendapat penilaian positif atau negatif, dimata mad'unya. Persepsi mad'u baik positif maupun negatif sangat berkaitan erat dengan penentuan penerimaan informasi atau pesan yang disampaikan dai. Semakin tinggi kredibilitas dai maka semakin mudah mad'u menerima pesan-pesan yang disampaikannya, begitu juga sebaliknya. ${ }^{9}$

Dari cara diatas menyimpulkan bahwa seorang dai harus sikap yang baik agar menjadi suri tauladan bagi mad'unya, bahkan dari cara memperkenalkan dirinyapun dinilai, bertutur kata yang baik, menyampaikan pesan dengan sistematis, efektif dan memiliki penguasaan materi, seperti dalam firman Allah QS al-Taubah/9 :122 yakni:

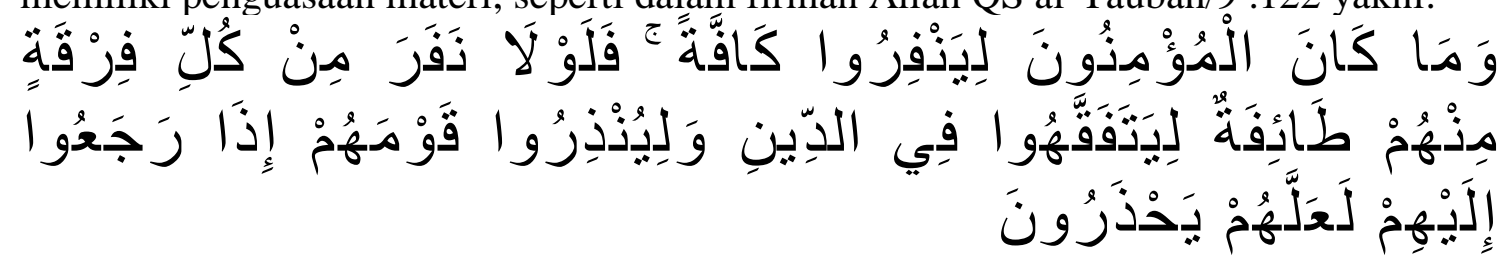

Terjemahnya:

"Tidak sepatutnya bagi orang-orang yang mukmin itu pergi semuanya (ke medan perang). Mengapa tidak pergi dari tiap-tiap golongan di antara mereka beberapa orang untuk memperdalam pengetahuan mereka tentang agama dan untuk memberi peringatan kepada kaumnya apabila mereka telah kembali kepadanya, supaya mereka itu dapat menjaga dirinya. (QS: Al-Taubah : 122). ${ }^{10}$

Dalam rangka mengoptimalkan kredibilitas dan membangun citra positif seorang dai perlu melingkupi tiga dimensi diantaranya yaitu: kebersihan batin, kecerdasan mental, keberanian mental.

Keteladanan yang aplikatif mempunyai pengaruh yang sangat kuat dalam penyebaran prinsip dan fikrah. Sebab itu merupakan kristalisasi dan wujud konkrit dari prinsip dan fikrah tersebut. Berbeda dengan ucapan-ucapan, caramah-ceramah, atau tulisan-tulisan terkadang para pendengar atau pembacanya tidak mampu mencerna, atau tidak mengerti maksud dan tujuannya. Hal yang paling dibutuhkan dalam menegakkan syariat Islam di muka bumi yakni teladan yang baik dalam setiap fase pembangunannya dan pada setiap unsur pembentuknya yaitu individu muslim, rumah tangga muslim, masyarakat muslim, pemerintahan Islam, Negara Islam serta khilafah Islam. ${ }^{11}$

Rasulullah Muhammad SAW sosok figur dai yang paling ideal, beliau memiliki ketiga kriteria di atas. Sehingga beliau memiliki citra positif di masyarakat. Beliau selalu memberikan solusi yang adil ketika terjadi perselisihan. Ketika diangkat menjadi Rasul beliau menjadi suri tauladan dalam berbagai aspek seperti aqidah, ibadah, muamalah dan akhlak, terpancar kesejatian, menjadi figur nyata bagi masyarakatnya,

\footnotetext{
${ }^{9}$ Enjah AS dan Aliyah, Dasar-Dasar Ilmu Dakwah, (Bandung: Widya Padjadjaran, 2009), h. 120.

${ }^{10}$ Departemen Agama R.I, Al-Quran dan Terjemahnya, h. 207.

${ }^{11}$ Syaikh Mushthafa Masyhur, Fiqh Dakwah, (Cet. II; Jakarta: Al-I’tishom, 2000), h. 548-549.
} 
dan segala kesempuranaan yang dimilikinya, beliau mampu menjadi pemimpin agama sekaligus negara. Kurang dari 23 tahun beliau mampu melakukan perubahan dari kejahiliahan kepada peradaban dunia yang tinggi.

b. Teori Medan Dakwah

Teori medan dakwah adalah teori yang menjelaskan situasi teologis, kultural dan struktural mad'u saat pelaksanaan dakwah Islam. Dakwah Islam adalah sebuah ikhtiar muslim dalam mewujudkan Islam dalam kehidupan pribadi, keluarga, komunitas, dan masyarakat dalam semua segi kehidupan sampai terwujudnya masyarakat yang terbaik atau dapat disebut sebagai khairul ummah yaitu tata sosial yang mayoritas masyarakatnya beriman, sepakat menjalani dan menegakkan yang ma'ruf dan secara berjamaa'ah mencegah yang munkar. ${ }^{12}$

Setiap Nabiullah dalam melaksanakan dakwah selalu menjumpai sistem dan struktur masyarakat yang di dalamnya sudah ada al-mala yaitu penguasa masyarakat, al-mutrafin yaitu penguasa ekonomi masyarakat konglomerat dan kaum al-mustad'afin yaitu masyarakat yang umumnya tertindas atau di lemahkan hak-haknya.

Dalam menghadapi segala bentuk struktur masyarakat seperti kaum al-mala, almutrafin dan al-mustad'afin dalam medan dakwah seorang dai perlu menerapkan etikaetika sebagai berikut:

1) Ilmu

Hendaknya memiliki pengetahuan amar ma'ruf nahi munkar dan perbedaan diantara keduanya. Yaitu memiliki pengetahuan tentang orang-orang yang menjadi sasaran perintah (amar) maupun orang-orang yang menjadi objek cegah (nahi). Alangkah indahnya apabila amar ma'ruf dan nahi munkar didasari dengan ilmu semacam ini, yang dengannya akan menunjukkan orang ke jalan yang lurus dan dapat mengantarkan mereka kepada tujuan.

2) Rifq (lemah lembut)

Hendaklah memiliki jiwa rifq, sebagaimana sabda Rasulullah Saw "Tidaklah ada kelemah lembutan dalam sesuatu kecuali menghiasinya dan tidaklah ada kekerasan dalam sesuatu kecuali memburukannya" (HR. Muslim).

3) Sabar

Hendaklah bersabar dan menahan diri dari segala perlakuan buruk. Karena tabiat jalan dakwah memang demikian. Apabila seorang dai tidak memiliki kesabaran dan menahan diri, ia akan lebih banyak merusak dari pada memperbaiki. ${ }^{13}$

Olehnya itu Allah swt. memerintahkan kepada Rasul-Nya, dimana mereka adalah penghulu para dai dan pelopor amar ma'ruf nahy munkar, untuk senantiasa bersabar.

Sebagaimana halnya tentang dakwah siyasah atau dakwah politik yang menjadi pembahasan dalam tesis ini, maka penulis mengemukakan tentang komunikasi politik. Karena dakwah, komunikasi dan politik memiliki korelasinya masing-masing.

Politik, seperti komunikasi adalah proses dan seperti komunikasi, politik melibatkan pembicaraan. Ilmuwan politik Mark Roelofs mengatakan sebagaimana yang telah dikutip oleh Dan Nimmo "politik adalah pembicaraan atau lebih tepat kegiatan

\footnotetext{
${ }^{12}$ Abdul Halim Ahmad, Di Medan Dakwah Bersama Dua Imam Ibnu Taimiyah dan Hasan AlBanna, (Surakarta: Era Intermedia, 2000), h. 178.

${ }^{13}$ Abdul Halim Ahmad, Di Medan Dakwah Bersama Dua Imam Ibnu Taimiyah dan Hasan AlBanna, h. 178-179.
} 
politik (berpolitik) adalah berbicara." Ia menekankan bahwa politik tidak hanya pembicaraan, juga tidak semua pembicaraan adalah politik. Akan tetapi, hakikat pengalaman politik, dan bukan hanya kondisi dasarnya ialah bahwa kegiatan berkomunikasi antara orang-orang. Dan Nimmo melanjutkan komunikasi meliputi politik. Bila orang mengamati konflik, mereka menurunkan makna perselisihan melalui komunikasi. Bila orang menyelesaikan perselisihan mereka, penyelesaian itu adalah halhal yang diamati, diinterpretasikan, dan dipertukarkan melalui komunikasi. Banyak aspek kehidupan politik dapat dilukiskan sebagai komunikasi. ${ }^{14}$

Jadi, dapat disimpulkan bahwa politik dan komunikasi merupakan dua hal yang saling melengkapi. Sejarah menjelaskan hanya dalam waktu beberapa bulan pascakejatuhan Soeharto, sudah lebih dari seratus partai politik didirikan. Hal ini wajar saja terjadi karena tingkat kemajemukan masyarakat, berikut kepentingan-kepentingan yang ada di dalamnya, cukup tinggi. Partai-partai politik tersebut antara lain partai yang bercorak Islam. Meskipun demikian, diantara partai-partai yang bercorak Islam itu memiliki cara pandang yang berbeda di dalam memahami relasi Islam dan politik, khususnya berkaitan dengan upaya untuk memperjuangkan nilai-nilai Islam di dalam kehidupan bernegara. ${ }^{15}$

Greg Fealy mengemukakan sebagaimana yang dikutip oleh Kacung Marijan membagi partai-partai bercorak Islam ke dalam 'Formalist Islamic Parties' dan 'pluralist Islamic Parties'. Yang dikelompokkan ke dalam 'formalist Islamic parties' diantaranya adalah PPP, PBB, dan PKS. Partai-partai demikian berusaha memperjuangkan nilai-nilai Islam ke dalam perundang-undangan dan kebijakankebijakan Negara. Sedangkan yang tergolong 'pluralist Islamic parties' antara lain, PKB dan PAN. Partai-partai demikian berusaha memperjuangkan nilai-nilai Islam di dalam konteks Negara bangsa Indonesia yang plural. ${ }^{16}$

Berdasarkan pandangan di atas sebenarnya dapat pula disimpulkan secara spesifik bahwa sampai saat ini PKS masih senantiasa menyatakan dirinya sebagai partai yang moderat.

Organisasi adalah suatu kumpulan atau sistem individual yang berhierarki secara jenjang dan memiliki sistem pembagian tugas untuk mencapai tujuan tertentu. De Vito menjelaskan sebagaimana yang dikutip oleh Burhan Bungin bahwa organisasi sebagai sebuah kelompok individu yang diorganisasi untuk mencapai tujuan tertentu. Jumlah anggota organisasi bervariasi dari tiga atau empat sampai dengan ribuan anggota. Organisasi juga memiliki struktur formal maupun informal. Organisasi memiliki tujuan umum untuk meningkatkan pendapatan, namun juga memiliki tujuan-tujuan spesifik yang dimiliki oleh orang-orang dalam organisasi itu. Untuk mencapai tujuan, organisasi membuat norma aturan yang dipatuhi oleh semua anggota organisasi. ${ }^{17}$

Organisasi memiliki suatu jenjang jabatan ataupun kedudukan yang memungkinkan semua individu dalam organisasi tersebut memiliki perbedaan posisi yang sangat jelas, seperti pimpinan, staf pimpinan dan karyawan. Masing-masing orang

\footnotetext{
${ }^{14}$ Dan Nimmo, Komunikasi Politik: Komunikator, Pesan dan Media, (Cet. VI; Bandung: PT Remaja Rosdakarya, 2005), h.8-9.

${ }^{15}$ Kacung Marijan, Sistem Politik Indonesia: Konsolidasi Demokrasi Pasca-Orde Baru, (Ed. I; Jakarta: Kencana Prenada Media Group, 2010), h.308-309.

${ }^{16}$ Kacung Marijan, Sistem Politik Indonesia: Konsolidasi Demokrasi Pasca-Orde Baru, h. 309310.

${ }^{17}$ Burhan Bungin, Sosiologi Komunikasi: Teori, paradigma, dan Diskursus Teknologi Komunikasi di Masyarakat, (Cet. V; Jakarta: Kencana, 2011), h. 277.
} 
dalam posisi tersebut memiliki tanggung jawab terhadap bidang pekerjaannya itu. Dengan demikian, komunikasi organisasi adalah komunikasi antarmanusia (human communication) yang terjadi dalam konteks organisasi dimana terjadi jaringan-jaringan pesan satu sama lain yang saling bergantung satu sama lain. ${ }^{18}$ Oleh karena itu, membangun jaringan komunikasi dalam sebuah organisasi merupakan hal yang sangat penting.

Fungsi komunikasi dalam organisasi yaitu fungsi informatif, regulatif, persuasif dan integratif. Fungsi informatif maksudnya seluruh anggota dalam suatu organisasi berharap dapat memperoleh informasi yang lebih banyak, lebih baik, dan tepat waktu. Fungsi regulatif ini berkaitan dengan peraturan-peraturan yang berlaku dalam suatu organisasi. Fungsi persuasif artinya dalam mengatur suatu organisasi, kekuasaan dan kewenangan tidak akan selalu membawa hasil sesuai dengan yang diharapkan. Adanya kenyataan ini, maka banyak pimpinan yang lebih suka untuk memersuasi bawahannya daripada memberi perintah. Sedangkan fungsi integratif yaitu setiap organisasi berusaha untuk menyediakan saluran yang memungkinkan karyawan dapat melaksanakan tugas dan pekerjaan dengan baik. ${ }^{19}$

Dalam konteks organisasi, pemahaman mengenai peristiwa-peristiwa komunikasi yang terjadi di dalamnya, seperti apakah instruksi pimpinan sudah dilaksanakan dengan benar oleh karyawan ataupun bagaimana bawahan mencoba menyampaikan keluhan pada atasan, memungkinkan tujuan organisasi yang telah ditetapkan dapat tercapai sesuai dengan hasil yang diharapkan, merupakan contoh sederhana untuk memperlihatkan bahwa komunikasi merupakan aspek yang penting dalam suatu organisasi, baik organisasi profit maupun nonprofit. ${ }^{20}$

Oleh karena dakwah siyasah merupakan dakwah politik yang berarti berhubungan dengan kepemimpinan. Salah satu teori kepemimpinan yang dapat dikemukakan yaitu teori konstelasi sifat. Dalam teori ini pemimpin memiliki sifat-sifat yang sama dengan yang dimiliki oleh siapapun, tetapi memadukan sifat-sifat ini dalam sindrom kepemimpinan yang membedakannya dari orang lain. Misalnya pemimpin itu lebih menonjol karena lebih tinggi, lebih besar, lebih bersemangat, lebih percaya diri, tenang dan sebagainya. ${ }^{21}$

Pola karir seseorang ditentukan oleh tingkat sosial ekonomi orang tua, kemampuan mental, pendidikan, keterampilan, karakteristik kepribadian (kebutuhan, nilai, kepentingan, sifat, dan konsep diri), dan kematangan karir serta kesempatan yang terbuka bagi dirinya. ${ }^{22}$

\section{METODOLOGI PENELITIAN}

Penelitian ini adalah penelitian lapangan (field research) untuk mengamati fenomena atau kenyataan tentang dakwah siyasah sebagai strategi dakwah Partai Keadilan Sejahtera (PKS) di Sulawesi Tenggara. Dengan begitu, dapat dikatakan bahwa penelitian ini bersifat deskriptif kualitatif. Artinya penulis menganalisis dan

\footnotetext{
${ }^{18}$ Burhan Bungin, Sosiologi Komunikasi: Teori, paradigma, dan Diskursus Teknologi Komunikasi di Masyarakat, h. 277-278.

${ }^{19}$ Burhan Bungin, Sosiologi Komunikasi: Teori, paradigma, dan Diskursus Teknologi Komunikasi di Masyarakat, h.278-280.

${ }^{20}$ Burhan Bungin, Sosiologi Komunikasi: Teori, paradigma, dan Diskursus Teknologi Komunikasi di Masyarakat, h. 261.

${ }^{21} \mathrm{http}$ ://komunikasi:juni 2013- indahnyanegeri.blogspot.com.2013-06 (7 Januari 2016)

${ }^{22} \mathrm{http}$ ://teoriperkembangankarirDonald E. Super-bambangdibyo.wordpress.com.2013/04 Januari 2016)
} 
menggambarkan penelitian secara objektif dan mendetail untuk mendapatkan hasil yang akurat.

Lokasi penelitian bertempat di Kota Kendari Sulawesi Tenggara yaitu strategi dakwah PKS di kota Kendari, Kab.Muna dan Anggota legislatif. Pemilihan lokasi ini sebagai objek penelitian didasarkan atas pertimbangan bahwa gerakan dakwah PKS menggunakan dakwah siyasah dengan sistem kaderisasi yang unik dan menarik serta memiliki keberagaman anggota atau kader dari segi usia, latar belakang pendidikan dan lain-lain juga didukung dengan masyarakat Sulawesi Tenggara yang masih mayoritas muslim. Penelitian ini penulis laksanakan sejak tanggal 8 juni sampai 27 Agustus 2015.

Pendekatan yang digunakan dalam penelitian ini adalah pendekatan normatif, dakwah, komunikasi dan pendekatan sosiologis. Sumber data primer berasal dari hasil wawancara peneliti dengan pengurus inti Partai Keadilan Sejahtera di Kota Kendari yakni ketua umum dan sekretaris umum, dan ketua bidang dakwah DPW Sulawesi Tenggara, sekretaris DPD PKS Kab.Muna dan anggota legislatif, tokoh masyarakat, tokoh pemuda serta dokumentasi mengenai pelatihan yang pernah diikuti oleh para kader. Sedangkan sumber data sekunder dalam bentuk dokumen yang telah ada yang dapat mendukung penelitian ini, seperti buku-buku yang menjelaskan tentang PKS, data dan dokumentasi penting yang menyangkut profil PKS, materi-materi dakwah dan data kader PKS yang menjadi anggota legislatif serta data base kader.

Data dikumpulkan melalui observasi, wawancara dan dokumentasi dengan instrumen masing-masing sesuai metodenya. Analisis data dilakukan melalui redukis data, penyajian data, dan penarikan kesimpulan. Data diuji keabsahannya dengan triangulasi sumber dan triangulasi teknik.

\section{HASIL PENELITIAN DAN PEMBAHASAN}

Islam merupakan agama yang lengkap dan sempurna, ajarannya mengatur hubungan dengan Allah (habluminallah) juga hubungan dengan sesama manusia (habluminannas) yang menyentuh semua dimensi kehidupan baik itu agama, pendidikan, hukum, ekonomi, budaya, politik dan lainnya. Sebagimana yang telah dijelaskan pada bab-bab sebelumnya bahwa tidak ada dikotomi antara dakwah dan politik dalam kamus PKS.

Seperti halnya yang diungkapkan oleh Hasan Al-Banna bahwa ketika berbicara politik, bukan semata-mata kekuasaan. Akan tetapi lebih kepada bagaimana mengurus dan menyelesaikan seluruh persoalan-persoalan keumatan.

Partai Keadilan Sejahtera (PKS) di Sulawesi Tenggara sadar akan tantangan dan peluang dengan terlibatnya para kader mereka pada politik praktis. Secara umum masyarakat saat ini sangat apatis terhadap dunia politik, terutama politik praktis karena kebanyakan orang atau kelompok yang terlibat dalam hal ini cenderung pragmatis. Partai-partai politik yang jumlahnya cukup banyak dalam sistem demokrasi saat ini dianggap gagal dalam mencetak pemimpin-pemimpin rakyat yang berkarakter dan berintegritas tinggi. Hal ini antara lain terlihat dari banyaknya kalangan politisi dan pengurus parpol yang terjerat kasus korupsi di tanah air termasuk beberapa tokoh PKS. Namun, PKS senantiasa memiliki cara untuk memanfaatkan peluang dan menghadapai tantangan-tantangan tersebut dengan membekali kader-kadernya agar memiliki karakter dan integritas yang tinggi sehingga layak untuk menjadi pemimpin-pemimpin rakyat yang jauh dari kepentingan pribadi dan kelompok. ${ }^{23}$

${ }^{23}$ La Pili (37 tahun), Sekretaris MPW PKS dan Anggota DPRD Provinsi Sulawesi Tenggara Observasi dan Wawancara, Raha, 25 Agustus 2015. 
Sebagaimana dijelaskan pada bab sebelumya bahwa PKS termasuk di Sulawesi Tenggara menggunakan metode tarbiyah islamiyah dalam membekali kader-kadernya yang mana pada hakikatnya menekankan setiap kader tarbiyah pada pembentukan syaksiyah islamiyah (kepribadian muslim) sebagai teladan bagi manusia dan syaksiyah daiyah (kepribadian dai) sebagai penyeru manusia untuk masuk ke dalam Islam.

Berkaitan dengan hal tersebut, pergolakan antara kepentingan dakwah dan politik dalam perjuangan PKS di Sulawesi Tenggara, dapat dilihat dari aspek kondisi riil kader sebagai dai dan politisi (kompotensi religius, sosial dan dakwah, negarawan, politik), dan kompotensi kepemimpinan serta pelatihan yang pernah diikuti.

\section{Kompotensi Religius (Kepribadian)}

Kompotensi religius adalah "sesorang yang memiliki kekuatan kepribadian, keyakinan, ideologi, nilai-nilai, pedoman dan integritas." ${ }^{24}$ Sebagaimana yang telah diketahui bahwa PKS dalam melakukan pembinaan kepada kadernya melalui wadah atau sarana yang dikenal dengan tarbiyah. Dan gerakan tarbiyah ini dilaksanakan bahkan sebelum PKS bermetamorfosis sebagai sebuah partai seperti saat ini. Karena menurut PKS di Sulawesi Tenggara metode dakwah melalui gerakan tarbiyah merupakan sarana yang efektif dalam menanamkan nilai-nilai ajaran Islam dalam setiap individu. $^{25}$

Para kader PKS di Sulawesi Tenggara sampai saat ini masih konsisten dan mampu membangun citra positif dan mencerminkan perilaku politik dan kinerja partai politik yang islami tanpa harus bersikap ekstrim. ${ }^{26}$ Hal ini menunjukkan bahwa PKS senantiasa melakukan pembaharuan pada sistem pengkaderannya agar mampu membentuk kepribadian kader-kadernya. Dalam hal ini melalui gerakan tarbiyah seperti liqo, halaqah dan sebagainya sehingga mampu menciptakan kader-kader berkualitas yang memiliki ideologi yang kuat, memiliki militansi yang sudah terlatih serta senantiasa mendorong kemampuan kadernya untuk masuk dan terjun di dalam partai serta dituntut untuk berkontribusi secara nyata. Karena bagi PKS keshalehan pribadi tidak berarti tanpa keshalehan sosial.

\section{Kompotensi Sosial dan Dakwah}

Sesorang yang disebut memiliki kompotensi sosial ialah yang memiliki keterampilan dan kemampuan sosial dalam berinteraksi dengan pribadi, kelompok atau masyarakat. Para kader PKS selalu sadar akan posisi mereka sebagai makhluk sosial, oleh karena itu untuk melaksanakan gerakan dakwah sangat penting diawali dengan partisipasi sosial dalam bentuk keterlibatan aktif dalam upaya pengokohan dan penyehatan kondisi masyarakat dalam segala aspeknya, ruhiyah, fikriyah, jasadiyah dan maliyah. $^{27}$

Dengan basis dukungan masyarakat yang kokoh, maka langkah berikutnya diharapkan akan menjadi lebih mudah. Kompotensi sosial tersebut meliputi kemampuan kader mengelola kegiatan sosial, dakwah dan tarbiyah, memiliki sikap solidaritas sosial serta mampu melakukan perbaikan hubungan antar individu, keluarga dan masyarakat.

\footnotetext{
${ }^{24}$ La Dahira (46 tahun), Ketua Bidang Dakwah Dewan Pengurus Daerah (DPD) PKS Kab. Muna Sulawesi Tenggara, Wawancara, 2 Agustus 2015.

${ }^{25}$ Arsip Dewan Pengurus Daerah (DPD) PKS Kab. Muna Sulawesi Tenggara, Observasi, JuniAgustus 2015.

${ }^{26}$ La Aris (43 tahun), Kepala Lurah Kec. Napabalano dan Tokoh Masyarakat, Wawancara, 2 Agustus 2015.

${ }^{27}$ La Pili (37 tahun), Sekretaris MPW PKS dan Anggota DPRD Provinsi Sulawesi Tenggara Observasi dan Wawancara, Raha, 25 Agustus 2015.
} 
Bagi PKS kompotensi ini sangat penting untuk senantiasa di pupuk dalam diri kaderkader partai agar senantiasa peka terhadap persoalan-persoalan umat atau masyarakat yang ada di sekitarnya. ${ }^{28}$

Partai Keadilan Sejahtera (PKS) di Sulawesi Tenggara memahami bahwa kader merupakan aset terbesar partai, oleh karena itu melakukan pembinaan dan pelatihan kepada kader-kadernya salah satu yang sangat penting. Misalnya salah satu kegiatan yang dilakukan yaitu dengan mengadakan sekolah murabbi. Dalam hal ini para kader dibekali keterampilan dalam membina seperti cara berkomunikasi intensif, bahasa tubuh, teknik menyampaikan materi, atau kajian dan lain-lain. ${ }^{29}$ Dengan kegiatan seperti ini tentu memupuk semangat kader baik dalam melaksanakan dakwah berupa merekrut kader maupun membina. Karena bagi kader-kader PKS iman itu akan terasa lebih manis jika ditularkan kepada orang lain.

\section{Kompotensi Negarawan}

Negarawan merupakan seseorang yang memiliki pandangan jauh ke depan. Kompotensi negarawan kader dapat dilihat dari kemampuan kader berkomunikasi dan berinteraksi dengan seluruh komunitas masyarakat muslim dan non muslim dengan baik. $^{30}$ Dengan kondisi perpolitikan yang sangat menghawatirkan di negeri ini, PKS menyadari akan pentingnya sosok seorang negarawan bukan sekedar seorang politisi saja apalagi hanya politisi pada politik praktis.

Oleh karena itu, sosok-sosok kader yang negarawan merupakan bagian yang sedang dan akan senantiasa diperjuangkan oleh PKS. Dalam hal ini, pengurus PKS di Sulawesi Tenggara tetap menggembleng kadernya melalui sarana-sarana tarbiyah. Dalam kamus kader-kader PKS sosok negarawan yaitu seseorang yang memiliki pandangan yang komprehensif, mampu menyatukan serta berkomunikasi dengan semua kelompok, partai maupun pandangan terlebih ketika suhu politik sedang memanas. ${ }^{31}$

Dengan demikian, kompotensi negarawan merupakan hal yang harus dimiliki oleh semua kader yang mana dalam perjuangannya menjadikan dakwah siyasah sebagai kendaraannya. Karena menjadi negarawan salah satu tolak ukur dalam meminimalisir atau mencegah terjadinya tarik-menarik kepentingan politik dan dakwah dalam tubuh Partai Keadilan Sejahtera (PKS) di Sulawesi Tenggara.

\section{Kompotensi Kepemimpinan}

Hasil tarbiyah membuat seorang kader memiliki kapasitas dan kualitas. Kompotensi kepemimpinan meliputi memiliki integritas keislaman yang kuat, komprehensif, dan syamil (terpadu, universal, dan integral), dikenal sebagai orang yang berkepribadian dan berakhlak mulia yang qawwam di keluarga dan berpengaruh di masyarakat, memiliki karakter rabbani yakni yang memiliki ilmu tentang Alquran, lalu mengamalkan dan mengajarkannya kepada masyarakat, serta mempunyai pemahaman tentang peranan kepemimpinan, politik dalam dakwah, serta tujuan dalam menegakkan nilai-nilai Islam. ${ }^{32}$

\footnotetext{
${ }^{28}$ La Dahira (46 tahun), Ketua Bidang Dakwah Dewan Pengurus Daerah (DPD) PKS Kab. Muna Sulawesi Tenggara, Wawancara, 2 Agustus 2015.

${ }^{29}$ Dewan Pengurus Daerah (DPD) dan Dewan Pengurus Wilayah (DPW) PKS Sulawesi Tenggara, Dokumentasi dan Observasi, Juni-Juli 2015.

${ }^{30}$ La Pili (37 tahun), Sekretaris MPW PKS dan Anggota DPRD Provinsi Sulawesi Tenggara, Wawancara, Raha, 25 Agustus 2015.

${ }^{31}$ Muhammad Poli ((40 tahun), Ketua DPW PKS dan Anggota DPRD Provinsi Sulawesi Tenggara, Observasi dan Wawancara, 29 Juni 2015.

${ }^{32}$ La Ode Muh.Dasnah (42 tahun), Ketua Bidang Dakwah DPW PKS dan Staf Ahli DPRD Provinsi Sulawesi Tenggara, Observasi dan Wawancara, Kendari 25 Juni 2015.
} 
Berdasarkan realita yang terjadi pada PKS di Sulawesi Tenggara, kaderkadernya senantiasa dibekali dengan berbagai pembinaan dan pelatihan melalui sarana yang sudah disiapkan dalam mewujudkan kompotensi kepemimpinan kader terutama kepada pengurus dan anggota legislatif. Misalnya dengan training kepemimpinan. ${ }^{33}$ Dengan citra positif yang senantiasa dibangun oleh para pengurus PKS dan anggota legislatif di Sulawesi Tenggara membuktikan bahwa mereka memiliki kompotensi kepemimpinan tersebut. Hal itu dibuktikan dengan profesionalitas mereka dalam melaksanakan kerja-kerja dakwah dan politik yang senantiasa bersinergi. ${ }^{34}$ Namun, membangun citra positif saja tidak cukup bagi seorang pemimpin dalam kepemimpinannya. Karena yang terpenting dari hal tersebut adalah memberikan kontribusi nyata dengan kerja-kerja dakwah yang bertujuan untuk kemashlahatan umat yang dicintainya.

\section{Kompotensi Politik}

Kompotensi politik merupakan salah satu bagian dari pergolakan dakwah dan politik dalam perjuangan PKS. Dalam membekali kadernya dengan kompotensi politik PKS melakukan pendidikan politik sebagai upaya untuk memberikan fondasi dasar mengenai siyasah/politik secara menyeluruh agar setiap kader mampu, senang dan aktif berperan serta dalam merealisasikan kemashlahatan sekaligus mencegah kemudharatan. Cara yang ditempuh antara lain dengan memberikan penerangan serta pemahaman kepada kader tentang berbagai persoalan umat, menanamkan kesadaran tentang pentingnya jihad fisabilillah (upaya pembebasan manusia dari perbudakan manusia lain atau oleh hawa nafsunya) sebagai pilar utama dalam menegakkan agama Islam. ${ }^{35}$

PKS menanamkan pemahaman tentang siyasah kepada kadernya sekaligus batasan-batasan moralitas politik kepada pengurus dan kader, memberikan kerangka konseptual tantang landasan-landasan syar'i terkait aktivitas berpolitik serta memberikan penguatan terhadap musyarakah siyasiyah (partisipasi politik). Dengan demikian tujuan dari tarbiyah bukan hanya terbentuknya pribadi muslim sebagai kader yang memiliki kesadaran semata, akan tetapi sekaligus kader yang turut serta dalam bidang poltik yang nantinya berpeluang dalam pembentukan kepribadian politiknya. ${ }^{36}$

Adapun metode yang diaplikasikan oleh PKS di Sulawesi Tenggara dalam hal ini meliputi ceramah dan diskusi/tanya jawab yang dilakukan dalam forum halaqah, dan sarana lain antara lain tasqif (tarbiyah tsaqafiyah), pelatihan (training) antara lain: Training Dasar (TD) yang meliputi TD-I, TD-II, training lanjutan (TL). Dan kajian (Kajian Ilmu Sosial Politik (KISP)) yang meliputi KISP-I, KISP-II, dan KISP-III dengan metode tambahan yang berupa praktek, mandiri, case study (studi kasus), panel, serta personal action plan. ${ }^{37}$ Dengan demikian dapat dikatakan bahwa dalam memberikan pemahaman politik kepada kadernya PKS menggunakan metode yang sangat variatif sesuai dengan perkembangannya.

\footnotetext{
${ }^{33}$ Dewan Pengurus Wilayah (DPW) PKS Sulawesi Tenggara, Observasi, Juni-Juli, 2015.

${ }^{34}$ La Pili (37 tahun), Sekretaris MPW PKS dan Anggota DPRD Provinsi Sulawesi Tenggara, Observasi dan Wawancara, Raha, 25 Agustus 2015.

${ }^{35}$ Muhammad Poli ((40 tahun), Ketua DPW PKS dan Anggota DPRD Provinsi Sulawesi Tenggara, Observasi dan Wawancara, 29 Juni 2015.

${ }^{36}$ La Ode Muh.Dasnah (42 tahun), Ketua Bidang Dakwah DPW PKS dan Staf Ahli DPRD Provinsi Sulawesi Tenggara, Observasi dan Wawancara, Kendari 25 Juni 2015.

37 Arsip Dewan Pengurus Wilayah (DPW) PKS Sulawesi Tenggara, Dokumentasi dan Observasi, Juni-Juli 2015.
} 
Kompotensi politik ini termasuk salah satu yang selalu diperjuangkan PKS di Sulawesi Tenggara, olehnya itu senantiasa dipersiapkan suatu proses belajar mengajar yang sistematis dan uniknya setiap materi ditentukan melalui proses interaksi.

Adapun dari segi materinya antara lain meliputi materi keislaman, kepartaian, pengenalan struktural PKS, wawasan politik dan sejarah, keterampilan/skill, dari segi pelengkap dengan penekanan sekaligus penguatan pada aspek keterampilan/skill, yang meliputi pengembangan diri dan kepemimpinan, manajemen dan organisasi. Dari segi pemerintahan sekaligus penguatan analisys capability (kapabilitas analisis) yang meliputi analisis hokum lokal, analisis ekonomi lokal, analisis sosial dan budaya lokal, analisis politik lokal, analisis birokrasi lokal yang di prioritaskan bagi calegnya. ${ }^{38}$ Perlu dipahami bahwa pembekalan kompotensi politik ini ditujukan pada pemberdayaan pengurus dan peran anggota legisltif.

Agar mencapai tujuan seperti yang diharapkan dalam merealisasikannya tidak hanya melalui doktrin siyasah akan tetapi mengggunakan sistem belajar (perkuliahan/persekolahan) sebagaimana halnya tasqif, sekolah pengurus, dan sekolah politik yang diimplementasikan PKS sebagai cara untuk menanamkan pemahaman politik melalui penyampaian materi siyasah, serta menyediakan praktek lapangan dan pelatihan siyasah meliputi keterampilan berpikir kritis, inovatif, dan kreatif, team building, dan produktivitas tim, teknik provokasi dan advokasi, keterampilan administrasi, jurnalistik, analisis SWOT, pengambilan keputusan, manajemen kampanye, teknik perencanaan dan sebagainya sebagai pembekalan pengalaman individu yang diharapkan dapat mengembangkan potensi siyasah kader. ${ }^{39}$

Tujuan dari pengembangan kompotensi ini tidak sebatas memberikan kesadaran secara konseptual teoritis akan tetapi sekaligus memberikan keteladanan politik praktis sebagai manifestasi kritalisasi kepribadian politik. ${ }^{40}$ Dengan demikian dapat dipahami bahwa melalui sistem pemahaman politiknya PKS hendak membangun legitimasi politik dengan komitmen dan konsistensinya dalam aktivitas dakwah politik sehingga memiliki peluang mengikis keputusasaan masyarakat akan perubahan ke arah lebih baik pada keadaan bangsa.

\section{Pelatihan}

Selain dari kompotensi-kompotensi yang telah dijabarkan di atas, pergolakan antara kepentingan dakwah dan politik yang sering menjadi dilema dalam perjuangan PKS dapat pula dilihat berdasarkan pelatihan yang pernah diikuti. Karena apabila seorang kader mendapatkan kenaikan jabatan pada tiap tingkatnya maka partai selalu melaksanakan pelatihan atau dalam bahasa internal partai yakni diklat. Khususnya yang terkait dengan kualitas dan militansi kader maka tentu akan berimplikasi pada peningkatan kerja-kerja dakwah dan politik kader. ${ }^{41}$

Berkaitan dengan pelatihan yang pernah diikuti oleh kader, untuk informasi bahwa PKS memang menyediakan dan memiliki diklat mulai dari Dewan Pengurus Ranting (DPRa) sampai Dewan Pengurus Pusat (DPP) hingga para pejabat publik,

38 Arsip Dewan Pengurus Wilayah (DPW) PKS Sulawesi Tenggara, Dokumentasi dan Observasi, Juni-Juli 2015.

39 Arsip Dewan Pengurus Wilayah (DPW) PKS Sulawesi Tenggara, Dokumentasi dan Observasi, Juni-Juli 2015.

${ }^{40}$ Sulkhani (40 tahun), Sekretaris Dewan pengurus Wilayah (DPW) PKS Sulawesi Tenggara, Wawancara, Kendari, 20 Agust us 2015.

${ }^{41}$ Sulkhani (40 tahun), Sekretaris Dewan pengurus Wilayah (DPW) PKS Sulawesi Tenggara, Wawancara, Kendari, 20 Agust us 2015. 
eksekutif serta legislatif. Karena yang menjadi objek penelitian penulis adalah wilayah Sulawesi Tenggara, maka untuk lebih jelasnya dapat diketahui melalui hasil pengamatan penulis terhadap data dokumentasi sebagaimana yang divisualisasikan pada tabel berikut:

Tabel 1.6

Struktur Program Diklat Tingkat DPW

\begin{tabular}{|c|c|}
\hline No & Kelompok dan Nama Materi \\
\hline $\mathbf{A}$ & Ideologi, Nilai-Nilai, Dan Manhaj Kepartaian \\
\hline 1. & Konsep PKS dalam mengelola pemerintahan \\
\hline 2. & Ijtihad dalam syura \\
\hline 3. & $\begin{array}{l}\text { Sejarah partai 4: analisis dan evaluasi faktor-faktor kelemahan, kekuatan dan } \\
\text { kesuksesan partai dalam Pemilu, Pilkada dan Pilpres (studi komparasi dengan } \\
\text { partai lain) }\end{array}$ \\
\hline $\mathbf{B}$ & Pengembangan Diri (Self Development) \\
\hline 1. & $\begin{array}{l}\text { Kontribusi peran kader: pengembangan diri untuk kematangan peran dalam } \\
\text { keahliannya }\end{array}$ \\
\hline 2. & Aktivitas protokoler dalam mengelola kegiatan partai \\
\hline 3. & Kepemimpinan sosial masyarakat dan keummatan \\
\hline 4. & Skill membangun networking \\
\hline 5. & $\begin{array}{l}\text { Teknik mempengaruhi opini media dan sarananya untuk mengkomunikasikan } \\
\text { ide }\end{array}$ \\
\hline $\mathbf{C}$ & Manajerial dan Organisasi \\
\hline 1. & Six-sigma dan balanced scorecard \\
\hline 2. & Knowledge Management \\
\hline 3. & Performance Management system \\
\hline 4. & Penerapan SMPD tingkat DPW \\
\hline 5. & $\begin{array}{l}\text { Organization Diagnosis IV/ DPW (tupoksi, struktur, pola hubungan, KPI, } \\
\text { control dan pengendalian) }\end{array}$ \\
\hline 6. & Sustainable Competitive Advantage \\
\hline $\mathbf{D}$ & Pemerintahan dan Sosial Politik \\
\hline 1. & Loby dan negosiasi (diplomasi) \\
\hline 2. & Peta politik level wilayah \\
\hline 3. & Program pemenangan Pemilu, pilpres, pilkada tingkat wilayah \\
\hline 4. & Manajemen publik \\
\hline 5. & Muatan lokal: membedah program pemerintah tingkat provinsi \\
\hline 6. & Muatan lokal: bahan masukan kebijakan daan reformisi di tingkat provinsi \\
\hline $\mathbf{E}$ & Sosial, Dakwah, Tarbiyah \\
\hline 1. & $\begin{array}{l}\text { Struktur social masyarakat provinsi, lembaga-lembaga dakwah, tokoh dan } \\
\text { ormas di tingkat provinsi }\end{array}$ \\
\hline 2. & $\begin{array}{l}\text { Permasalahan (isu-isu kontemporer) dan solusi masalah masyarakat tingkat } \\
\text { provinsi }\end{array}$ \\
\hline $\mathbf{F}$ & Aplikasi \\
\hline 1. & $\begin{array}{l}\text { Misi, kebijakan, manajemen partai dan program kaderisasi tingkat DPW } \\
\text { (formulir isian) }\end{array}$ \\
\hline 2. & $\begin{array}{l}\text { Kunjungan: kantor pemda/lembaga pemerintahan, lembaga bisnis, media } \\
\text { Koran/elektronik, lembaga sosial/dakwah, tokoh }\end{array}$ \\
\hline 3. & $\begin{array}{l}\text { Rencana strategi: profil (pengenalan medan, peta potensi, peta politik, dan } \\
\text { profil pem kec.), perencanaan program tingkat DPW }\end{array}$ \\
\hline
\end{tabular}


\begin{tabular}{|l|l|l|l|}
\hline 4. & Program wajib baca dan resensi & & \\
5. & Menulis dan orasi politik & & \\
\hline & Mencermati tabel di atas maka dapat disimpulkan bahwa PKS dalam
\end{tabular} mengembangkan kualitas kader melaksanakan berbagai pelatihan yang dapat mendongkrak potensi-potensi kadernya yang kemudian disiapkan untuk menjadi pejabat-pejabat publik, eksekutif maupun legislatif. ${ }^{42}$ Dengan tujuan agar dapat menciptakan kader dakwah yang unggul dan tangguh dalam memperjuangkan kepentingan-kepentingan umat di rana publik.

Berdasarkan hasil penelusuran penulis terhadap data dokumentasi semua pengurus di tingkat DPW di wilayah Sulawesi Tenggara sudah mengikuti beberapa pelatihan yang sudah disiapkan tersebut. Akan tetapi menurut salah seorang anggota legislatif, mereka saat ini yang mendapatkan kursi di DPRD provinsi maupun kota telah mengikuti pelatihan-pelatihan tersebut. Hal ini dikarenakan bahwa dari tingkat Dewan Pengurus Ranting (DPRa) sampai Dewan Pengurus Pusat (DPP) PKS memang memiliki format pelatihan tersebut dan harus dilaksanakan serta diikuti oleh para kader pengurus partai di seluruh wilayah Indonesia termasuk Sulawesi Tenggara. Hal yang demikian menunjukkan kalau PKS dapat memberikan jenjang karir politik jika dilaksanakan dengan benar tanpa memandang latar belakang keturunan, pendidikan dan lainnya. ${ }^{43}$

\section{KESIMPULAN}

Kepentingan dakwah dan politik dalam perjuangan PKS di Sulawesi Tenggara bukanlah menjadi persoalan yang berarti karena para kader terutama yang menjadi anggota legislatif ditingkat provinsi dan kota/kabupaten cukup dinamis dalam memerankannya. Terutama bagi mereka yang terlibat langsung dalam politik praktis, yakni mereka yang sudah teruji komitmen dan loyalitasnya terhadapa ajaran Islam. Dan tentu saja telah memiliki kredibitas yang tinggi bukan saja dalam pandangan internal partai akan tetapi dalam kehidupan masyarakat juga. Sebagaimana dalam konsep teori citra dai bahwa semakin tinggi kredibilitas seseorang maka semakin tinggi tingkat pemerimaan orang lain terhadapnya.

Begitu pula dengan teori medan dakwah yang memiliki konsep tentang gambaran teologis, kultur dan struktural seorang mad'u. Para kader PKS yang dinobatkan untuk bertarung dalam politik praktis tentunya sudah dipahamkan sekaligus memahami dunia tersebut begitupun peluang dan tantangannya. Misalnya mitra mereka bekerja sebagai anggota legislatif jelas bukan saja sesama mereka dari internal PKS akan tetapi dari berbagai partai. Banyak perbedaan diantara mereka antara lain, agama, ideologi dan lain sebagainya. Meskipun demikian tidak serta merta membuat para anggota legislatif PKS berkecil hati karena mereka memahami medan dakwah yang mereka tempuh. Hal itu dikarenakan tujuan utama PKS berpolitik adalah agar kepentingan dakwah bisa berjalan sebagaimana yang diharapkan.

\footnotetext{
${ }^{42}$ Arsip Dewan Pengurus Wilayah (DPW) PKS Sulawesi Tenggara, Dokumentasi dan Observasi, Juni-Juli 2015.

${ }^{43}$ Arsip Dewan Pengurus Wilayah (DPW) PKS Sulawesi Tenggara, Dokumentasi dan Observasi, Juni-Juli 2015.
} 


\section{DAFTAR PUSTAKA}

Ahmad, Abdul Halim. Di Medan Dakwah bersama Dua Imam Ibnu Taimiyyah dan Hasan Al Banna, Surakarta: Era Intermedia, 2000.

AS, Enjah dan Aliyah. Dasar-Dasar Ilmu Dakwah, Bandung: Widya Padjajaran, 2009.

Bungin, Burhan. Sosiologi Komunikasi: Teori, Paradigma, dan Diskursus Teknologi Komunikasi di Masyarakat, Cet.V; Jakarta: Kencana, 2011.

Departemen Agama RI, Al-Quran dan Terjemahannya, Jakarta: Al-Huda, 2002.

Idris, Malik. Strategi Dakwah Kontemporer, Cet.I; Makassar: Sarwah Press, 2007.

Kusnawan, Aep. Ilmu Dakwah (Kajian Berbagai Aspek), Bandung: Pustaka Bani Quraisy, 2004

Luth, Thohir. M. Nasir: Dakwah dan Pemikirannya, Cet: I; Jakarta: Gema Insani Press, 1999.

Marijan, Kacung. Sistem Politik Indonesia: Konsolidasi Demokrasi Pasca-Orde Baru, Ed. I; Jakarta: Kencana Prenada Media Group, 2010.

Masyhur, Syaikh Musthafa, Fiqh Dakwah, Cet.I; Jakarta: al-“I'tishom, 2000.

Nasution, Harun. Islam Ditinjau Dari Berbagai Aspeknya, Cet. V; Jakarta: UI Press, 1985.

Nimmo, Dan. Komunikasi Politik: Komunikator, Pesan dan Media, Cet. VI; Bandung: PT Remaja Rosdakarya, 2005.

\section{Sumber Internet:}

“PKS Visi dan Misi”, Situs Resmi Dewan Pengurus Pusat Partai Keadilan Sejahtera. www. Pks.or.id/mobile/content.html? (19 Mei 2015).

http://komunikasi:juni 2013- indahnyanegeri.blogspot.com.2013-06 (7 Januari 2016)

http://teoriperkembangankarirDonaldE.Superbambangdibyo.wordpress.com.2013/04 (7 Januari 2016) 